Hambalík Alexander, Ing., PhD. -

Institute of Computer Science and Mathematics, alexander.hambalik@stuba.sk

Marák Pavol, Ing.

FEI Slovak University of Technology Bratislava

pavol.marák@stuba.sk

\title{
VIRTUÁLIS LABORATÓRIUM BIOMETRIA TÉMÁJÚ OKTATÁSHOZ ÉS KUTATÁSHOZ
}

\section{Bevezetés}

Sokan, sokféle technológia segítségével igyekeztek megoldani a mindennapi élet és a kriminológia alapvető problémáját, az identifikáció és autentifikáció folyamatát, beleértve a mobilalkalmazásokat is. Hasonló a helyzet az évtizedek óta alkalmazott daktiloszkópia esetében, ahol máig nem bizonyított az ujjlenyomat ismételhetetlen egyedisége és az átfogó, nagy mintákon végzett tartalomelemzésük is hiányzik. Az előbbiek, saját tapasztalataink és a nyomasztó szakemberhiány inspirálta azt a jelenleg is folyó kutatást és fejlesztést, mely célja univerzálisan alkalmazható, hálózat alapú, virtuális laboratórium létrehozása. A BiometriX 2017 labor daktiloszkópia moduljai közül jelenleg A Fingerprint Expert fejlesztése van a legelörehaladottabb állapotban. Az ujjlenyomatok, helyszíni felvétele, beolvasása, előfeldolgozása, tartalmuk CUDA kóddal gyorsított (többségében saját algoritmusú), képpont mátrix és neuronhálozat alapú felismerése már szerves része a modulnak. A rendszert egy Android operációs rendszerben müködő, hasonló feladatok elvégzésére tervezett mobilaplikáció kísérleti változata egészít ki. Természetesen jóval szerényebb felszereltségü, kisebb teljesítményü, de ez a mobilalkalmazás is fontos eleme a laboratóriumnak az oktatásban vagy a terepmunkában.

A labor gyakorlatilag a biometria bármely feladatának megfelelően korlátlanul bővíthető a hardver és erőforrásai keretein belül, de a folyamatban levő felhőtechnológiák beépítése ezt a korlátot is áthidalhatja. A kísérleti változat eredményei alapján már most kijelenthetjük, hogy az eredmények nagyon biztatóak. A többi ismert rendszerrel összevetve nagy elönye az, hogy nemcsak a leggyakrabban elöforduló két minúciát (végpont, elágazás) ismeri fel, de a többi ismert, gyakoribb, vagy ritkábban előforduló alakzatot is. Jelenleg ilyen szintü elemzést csak szakértő végez, hosszadalmas kézi munkával. A mintakészletet a belügyminisztériumhoz tartozó Szlovák Köztársaság Rendőrségének Kriminológia és Szakértői Intézetével egy korábbi közös kutatómunka keretében kidolgozott javaslat alapján telepítettük. További elönye a rendszernek az, hogy szakértő üzemmódba kapcsolva a feldolgozás paraméterei széles spektrumban változtathatók és a részeredményeket is tudja vizualizálni. Mindez az ujjlenyomatok komplex tartalomelemzését is lehetővé teszi, mely elsősorban az alapszintütől a szakértői szintü oktatásban és a kutatómunkában hasznosítható hatékonyan.

Analízisre bementként fekete-fehér lenyomatképet vár FBI kompatibilis 500 DPI vagy nagyobb felbontásban. Természetesen ujjlenyomat olvasó is kapcsolható hozzá helyszíni, azonnali beolvasáshoz. Alapértelmezett kimenete a kijelzőre irányul, de menteni, és nyomtatni is lehet a részletekig szinte minden fontosat. 


\section{Honnan az inspiráció?}

Azt, hogy egy ilyen rendszer fejlesztésébe belefogtunk több tényező és esemény is befolyásolta. Egy közös kutatómunka a már említett, daktiloszkópiával nagyon magas szinten foglakozó intézménnyel, az érvényes helyi és nemzetközi elöírások megismerése valamint a daktiloszkópiában alkalmazott gyakorlati munkafolyamatok megismerése hozta az első ilyen gondolatokat.

A megközelítőleg egy évszázada intenzívebben használt daktiloszkópia eredményei eljutottak a mindennapi használatig [1]. Ennek ellenére sok dologban a tudomány az időközben szerzett tapasztalatokat ugyan használja, de esetenként érvényességüket exakt módon bizonyítani nem tudja. Ez nemcsak a részletekre vonatkozik, de az alapvető dolgokra is.

Az eddigi, hosszabb távú gyakorlati tapasztalatok alapján állítható: Nem létezik két személy azonos ujjlenyomat mintázattal. Valójában máig nem bizonyított az ujjlenyomat ismételhetetlen egyedisége. Miért? Hiányzik az átfogó, nagy mintákon végzett teljes körü tartalomelemzésük - kézi erővel lehetetlen, a gép pedig még nem kellőképpen ismer fel minden alakzatot (minúciát).

Összességében tehát a megoldatlan elméleti és gyakorlati dolgok, a legiszlatíva (szabályozás) hiányosságai, hibái, a nagy szakember- és megfelelő laboratórium inspirált bennünket. A célt egy kutatásra, oktatásra alkalmas, hálózat alapú, könnyen hozzáférhető, biztonságos és jól kezelhető virtuális biometria laboratórium fejlesztésében határoztuk meg.

\section{A BiometriX 2017 virtuális laboratórium}

Ahogyan azt már a bevezetőben jeleztük, a biometria egyik fontos feladata megoldani a mindennapi élet és a kriminológia (daktiloszkópia) alapvető problémáit. Közülük a két legfontosabb az:

- identifikáció és

- autentifikáció.

Az identifikáció leegyszerűsítve a „Ki vagy a sok közül?” kérdésre keresi a választ. Az adatbázisban ehhez például egy ujjlenyomat mintát próbál az összes többi tárolttal összehasonlítani (1:n).

Az autentifikáció ehhez képest egy kicsit egyszerübb feladatot old meg. Egy ismert személyt (login, stb. alapján) próbál a „Valóban te vagy az?” kérdésre kapott válasszal autentifikálni. Az adatbázisban ehhez csak egy mintával kell az ujjlenyomatát összehasonlítani (1:1).

Ezek mindegyike bonyolult képfeldolgozáson alapuló, mégis a biometria szempontjából aránylag egyszerü feladatok, melyeket már az ismert technológiák is egészen jól kezelnek, támogatnak egészen a mobilalkalmazások szintjéig.

Sokkal bonyolultabb viszont az a feladat, hogy megismerjük, valójában mit is tartalmaznak az ujjlenyomatok. Ehhez tüzetesen kellene megvizsgálni legalább alapszinten minden földrész adatbázisában található ujjlenyomatot.

A BiometriX 2017 virtuális laboratóriumot egy olyan rendszernek terveztük, amelyik a lehetőségeihez mérten az egyszerübb és az összetettebb feladatok megoldására is alkalmas legyen. Mindamellett segítse a szakemberképzést, a kutatást, ha kell laboratóriumi környezetben, oktatóközpontokban, de a sokszor elengedhetetlenül szükséges terepmunkában is.

\section{A BiometriX 2017 alapvető tulajdonságai}

A rendszert már több éve fejlesztjük egy a Szlovák Rendőrség Kriminológia és Szakértői Intézetével végzett kutatási munka óta. Az első fejlesztések inkább önálló felhasználói programok voltak különböző környezetekben megvalósítva. Elsődleges feladatuk az volt, hogy 
felmérhessük a lehetőségeket és a kifejlesztett algoritmusok helyességét (részletek az Irodalomjegyzékben [2-21] források tartalmazzák). Lehet-e és hogyan azt a 12 minúciát felismerni, amelyeket a szakértői intézettel közösen (a nemzetközi gyakorlatot is figyelembe véve) választottunk ki alapként. Sajnos világ- vagy legalább európai szinten felmérve a helyzetet máig nincs erre a célra használható, egységesen elfogadott mintakészlet.

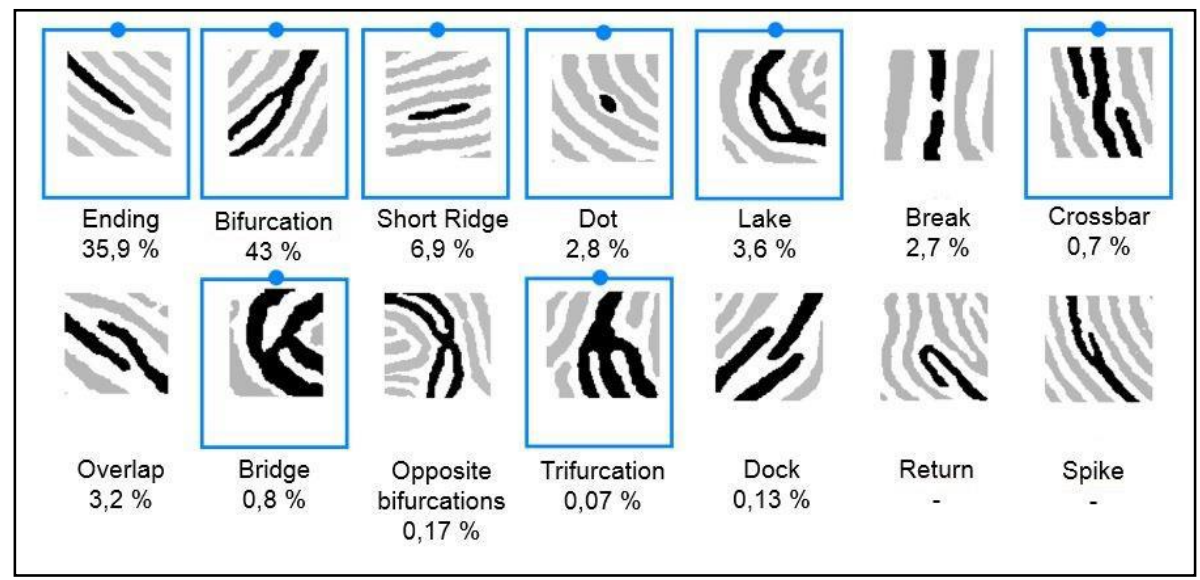

1. ábra. A Szlovák Rendörség Kriminológia Szakértöi Intézetével végzett kutatáshoz kiválasztott mintakészlet (12 minúcia az elöfordulási koeficiensekkel egy ujjlenyomatban)

Két alapvető módszerrel képes az ujjlenyomatok 2D képeit (fekete fehér) feldolgozni L1 (globális), L2 (részlet) szintü mintafelismeréssel. Ez történhet:

a) előfeldolgozással,

b) előfeldolgozás nélkül.

A labortórium központi része egy erre a célra épített Xeon alapú, többmagos és többprocesszoros szerver. A teljes parancskészletü (CISC) processzorok úgy tünik, elég gyorsan megoldják a rájuk váró feladatokat. A speciális igényü egycélú, paralellizálható számításokhoz a többletteljesítményt a szerver extra teljesítményü grafikus kártyájának processzora adja. Több tíz magú és nagyon gyors processzorról van szó, amely az addigi eredmények alapján föleg a neuronhálózatos feldolgozást gyorsítja látványosan. Ha szükség lesz rá, ebböl akár kettő is müködhet majd a közeljövőben (egymást áthidalva párhuzamosan, egy egységként).

A hálózati kommunikációt kettő, kicsit a jövő hálózataihoz dimenzionált, 10G átvitelt biztosító kártya szolgálja.

Mi változott az óta, hogy a BiometriX 2017 rendszert kezdtük el fejleszteni? Az alapoktól kezdve szinte minden. A BiometriX 2017 már szerver alapú rendszer, annak minden előnyével és hátrányával, mobilalkalmazással kiegészítve.

- Gyakorlatilag egy távolról jól hozzáférhető, grafikus felületet is alkalmazható, virtuális laboratórium biometria témájú kutatáshoz, oktatáshoz.

- A Fingerprint Expet modulja képes biztonságos, akár folyamatos ujjlenyomat vételt biztosítani helyi, vagy távoli szkenner segítségével, azonnali grafikus megjelenítéssel.

- A felhasználó számára a folyamat szinte minden részlete ellenőrizhető, ha szükséges. A feldolgozás elöre beállított paraméterek mellett is folyhat.

- A feldolgozás módja és paraméterei széles körü lehetőségekből választható ki, állítható be a felhasználói felületen, de előre beállított módon is végezhetö.

- Egy időben többen is használhatják majd a rendszert ügyelve a biztonságra, adatvédelemre.

- Müködhet web hozzáféréssel nyitott, vagy privát hozzáféréssel zárt rendszerként.

- A felhőtechnológiák beépítése is folyamatban van. 
- A mobilalkalmazás jelenleg még csak önállóan fut a gépeken, de a közeljövőben ez is részévé válik a hálózati rendszernek.

- A bemeneti oldalon több típusú szkenner is csatlakoztatható hozzá az eddigi egy helyett.

- Természetesen tud már másutt felvett és digitalizált 2D ujjlenyomatokkal is dolgozni.

A felhasznált algoritmusok többsége már tesztelve volt, ezért az új rendszerbe sokkal jobban optimalizálva építettük be ezeket. Ez jelentős időt faragott le az ujjlenyomatok feldolgozásának idejéböl.

A fejlesztés alatt felhasznált ujjlenyomatok két forrásból származnak. Nyilvánosan hozzáférhető adatbázisokból és a rendszer bemeneti részét képező ujjlenyomat olvasó szkenner valós használatának kimenetéröl. Több típust is használunk. Az egyszerübb, kis tömegü, könnyen hordozható egyujjastól a terjedelmesebb méretü, inkább asztali használatra alkalmas nagyon pontos változatig. Felbontásuk 500-1000 DPI között van és mindegyik USB csatlakozóval köthető a rendszerbe. A kisebbek (pl. Futronic FS80) inkább az oktatásra a nagy felbontásúak (pl. HiScan-PRO) kutatásra is alkalmasak és teljesítik az FBI kívánalmakat. Mindegyiknek megvan a kivitelből eredő maga előnye és hátránya és a szélesebb választék segít a rendszer jobb, pontosabb tesztelésében.

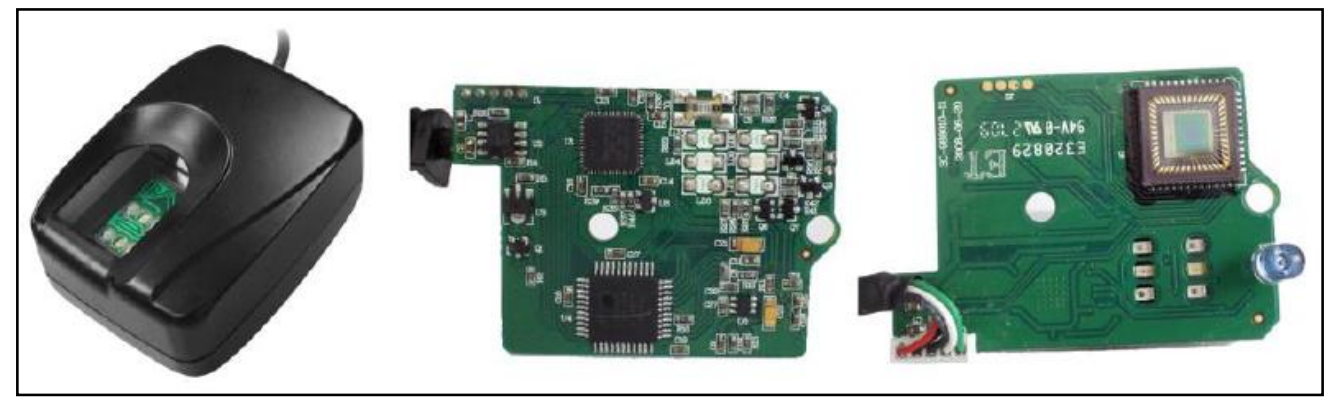

2. ábra. Egyik típusa az általunk használt ujjlenyomat szkennereknek: Futronic FS80 - FBI certifikált változata FS88 jelöléssel forgalmazott

A kép formátumban megérkezett ujjlenyomatot a rendszer az általunk kiválasztott módszerekkel dolgozza fel. Jelenleg még a neuronhálózat alapú feldolgozás esetében is az előfeldolgozás szükséges. Ennek segítségével derítjük fel az analízis tárgyát képező minuciák helyzetét.

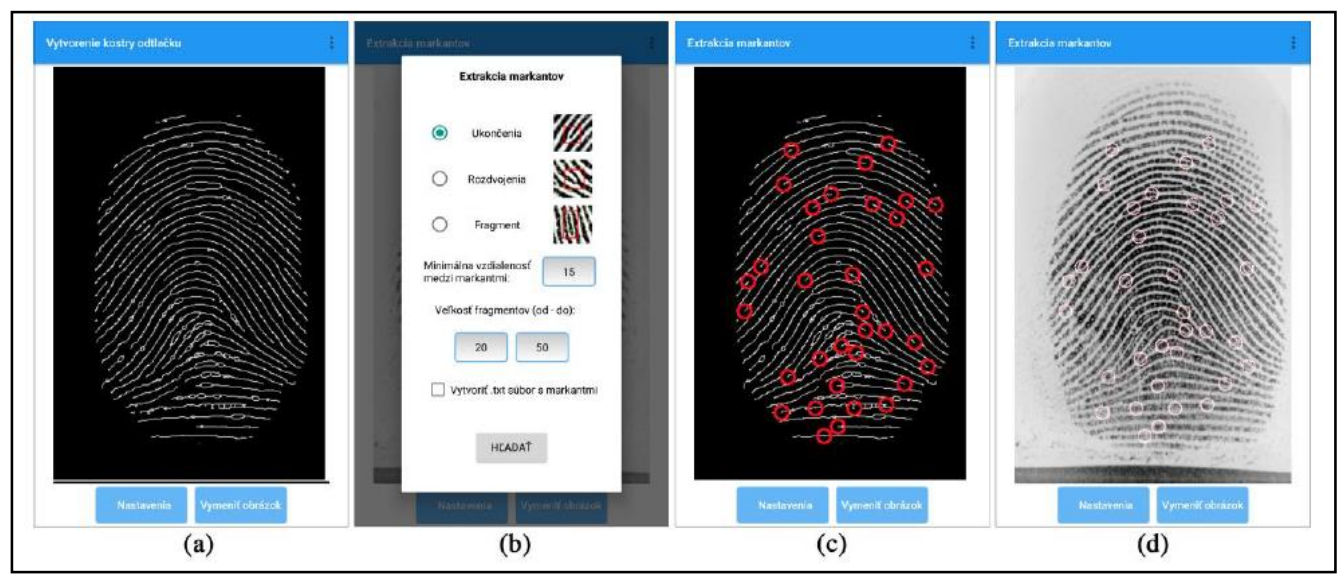

3. ábra A mobilalkalmazás néhány felülete

A nagyobb teljesítményü szerver esetében már dolgozunk egy változaton, amelynél ez a lépés kimaradhatna. 
A betanításhoz szükséges minúcia mintákat egy erre a célra készített program segítségével gyüjtjük be. Kivágáskor a mintavétel helye, alapterülete állítható. A különböző helyzetü minták paramétereit a kivágott minta képével együtt állományba mentve archiváljuk.

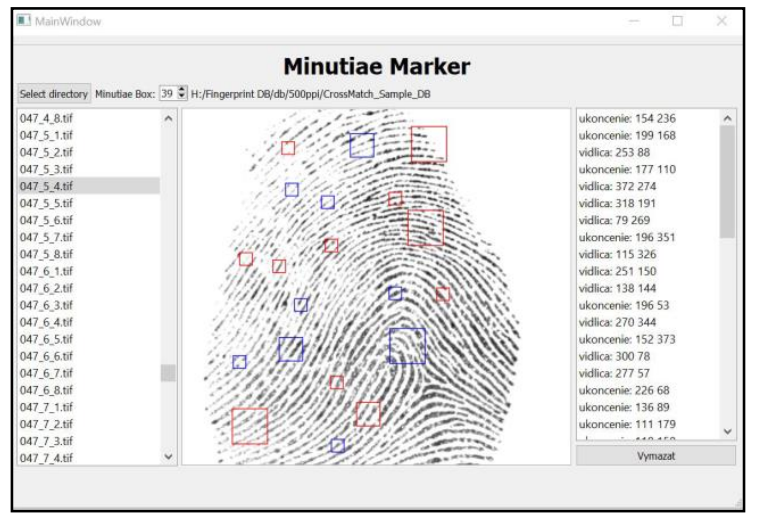

4. ábra. Saját kódú „,célszerszám” a neuronhálózat betanitásához használt minták kivágására

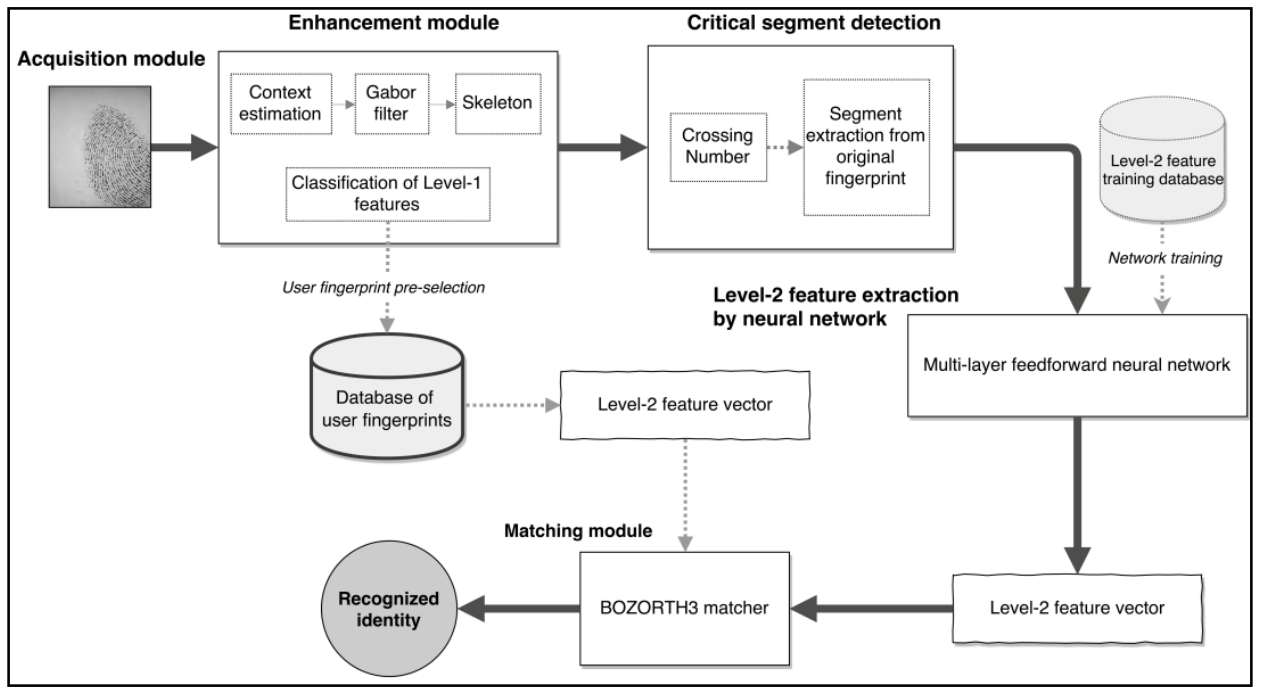

5. ábra. A neuronhálózat alapú analízis menete

Az újabb, neuronhálózatos modulnál, minúcia felismerésnél az előfeldolgozás és az ezzel keletkezett pontatlanságok, deformációk már nem lesznek jelen.

\section{Az elért eredményekről}

Az itt megjelenítettek a virtuális laboratórium legelörehaladottabb fejlesztésü modulja a Fingerprint Expert és az önálló mobilalkalmazás segítségével készültek. A többi hasonló rendszerekhez képest nagy előnye az, hogy a mintakészlet szinte minden minúciáját képes valamilyen módszerrel felismerni, ami elsősorban a szakértői szintủ alapos kutatást és oktatást segíti. Szakértői üzemmódban szinte minden használt paramétere változtatható a részeredmények vizualizálásával, mentésével, együtt.

A végleges változatok felhőtechnológiákat is alkalmazva ennél jóval több és pontosabb eredményt képesek majd nyújtani, a hálózati rendszerek minden előnyével és hátrányával. Az alkalmazott algoritmusok tesztelésekor már a BiometriX 2017 változatot megelőző alkalmazások is nagyon jó eredményeket értek el mind a feldolgozás gyorsaságában, mind a pontosság terén (a minták típusának, pontos helyének meghatározásával). 
Az ujjlenyomat azonosítása nem tartozik a rendszer elsődleges feladatai közé, ennek ellenére a szakirodalomban FMR és FNMR (a tévedések mértékét kifejező együtthatók, melyek a jogos, illetőleg nem jogos elutasítást vagy megengedést fejezik ki) esetében is képes az ismert rendszerek legjobbjaival lépést tartani. Reményeink szerint a kódok, algoritmusok további átalakításával, pontatlanságok, kijavításával az eredmények még jobbakká válhatnak. A legnagyobb előnyét az új rendszernek mégis az új hálózati technológiák effektív használata adja. Ezek valós pozitív (negatív) hozatalát ma még csak nehezen lehet felmérni.

\section{Befejezés}

Megpróbáltuk felvázolni a BiometriX 2017 rendszert, lehetőségeit és a fejlesztése fázisait. Mivel a kutatómunka és a rendszer fejlesztése egyidőben folyik, sok még a ránk váró feladat. Bár az új rendszer fejlesztése még csak aránylag rövid ideje folyik és a megelőző változatokhoz képest sok új technológia beépítését igénylik, az eredmények nagyon bíztatóak. Azon kívül, hogy a számítások gyorsabban és pontosabban folynak a jobban, áttekinthetőbben megírt forráskódok, modulok csökkentik a tervezés és a fejlesztés idejét, rövidítik a tesztelés folyamatát. A kimenetek és a bemenetek nemzetközi szabványokhoz való hozzáigazítása még előttünk van, ennek ellenére az adatok, eredmények archiválása és esetleges újrafeldolgozása már a jelenlegi formában is megvalósítható.

A moduláris rendszer a biometria szinte minden területén használható majd, mert elsősorban széles spektrumú kutatásra és oktatásra terveztük.

\section{A kutatómunka a VEGA 1/0159/17 Bezpečná postkvantová kryptografia/ Secure post- quantum cryptography pályaterv keretében és támogatásával jött létre.}

\section{Irodalomjegyzék}

Maltoni, D. et al. Handbook of Fingerprint Recognition: Second Edition. London: Springer, 2009. 496 p. ISBN 978-1- 84882-253- 5. https://doi.org/10.1007/978-1-84882-254-2

Marák, P. - HAMBALÍK, A. Software System for Processing and Analysis of Fingerprints and Determination of Necessary Parameters. Proceedings of the 1st International Conference and Exhibition on Future RFID Technologies, Eger, Hungary, November 5-7, 2014.

Ameríny, L et. al., A SIFT-based forensic method for copy-move attack detection and transformation recovery. IEEE Transactions on Information Forensics and Security, vol. 6, issue 3, pp. 10991110, 2011. https://doi.org/10.1109/TIFS.2011.2129512

Lowe, D. G. Distinctive Image Features from Scale-Invariant Keypoints, Computer Science Department. University of British Columbia, January 5, 2004.

Tkáčik, P. Automated system for recognition of originality of image. [Master thesis - supervised by A. Hambalík], FEI STU Bratislava : Bratislava, 2015.

Grznár, M. Biometric recognition: fingerprint image enhacement algorithms. [Bachelor thesis supervised by P. Marák], FEI STU Bratislava : Bratislava, 2015.

Hoferica, O. Possibilities of application of neural networks in the field of fingerprint biometric systems. [Bachelor thesis - supervised by P. Marák], FEI STU Bratislava : Bratislava, 2015.

Majzel, M. Android application for fingerprint sensing and processing using external sensor. [Master thesis - supervised by A. Hambalík], FEI STU Bratislava : Bratislava, 2016.

Majzel, M. Methods of Fingerprint Pattern Preprocessing and Feature Extraction. [Bachelor thesis supervised by P. Marák], FEI STU Bratislava : Bratislava, 2014.

Czakó, G. Opensource network system for efficient preprocessing of fingerprint minutiae - neural network method. [Master thesis - supervised by A. Hambalík], FEI STU Bratislava : Bratislava, 2016. 
Kollman, L. Opensource network system for efficient preprocessing of fingerprint minutiae. [Master thesis - supervised by A. Hambalík], FEI STU Bratislava : Bratislava, 2016.

Dický, M. Person identity model based on fusion of Level-1 and Level-2 fingerprint features. [Bachelor thesis - supervised by P. Marák], FEI STU Bratislava : Bratislava, 2016.

Smolen̆, M. Automated fingerprint identification system based on client-server architecture. [Bachelor thesis - supervised by P. Marák], FEI STU Bratislava : Bratislava, 2016.

Taraj, M. The experimental software tool for recognition of extended set of Level-2 fingerprint properties. [Bachelor thesis - supervised by P. Marák], FEI STU Bratislava : Bratislava, 2016.

Toman, M. Present Fingerprint Matching Algorithms. [Bachelor thesis - supervised by P. Marák], FEI STU Bratislava : Bratislava, 2016.

Úroda, J. Artificial Neural Networks and Their Application in Critical Processing Stages of Fingerprint Recognition System. [Bachelor thesis - supervised by P. Marák], FEI STU Bratislava : Bratislava, 2016.

Kádek, L. Processing and recognition of complex minutiae in dactyloscopic prints. [Bachelor thesis supervised by A. Hambalík], FEI STU Bratislava : Bratislava, 2016.

Gáži, T. Inaccuracies in fingerprint image and its possible elimination in practice. [Master thesis supervised by A. Hambalík], FEI STU Bratislava : Bratislava, 2016.

Mokráš, R. Processing and analysis of fingerprints using multi core processor. [Master thesis supervised by A. Hambalík], FEI STU Bratislava : Bratislava, 2016.

Hoferica, O. et al. Neurodactyl. [Team project - supervised by A. Hambalík and P. Marák], FEI STU Bratislava : Bratislava, 2016.

Bujňák, E. et al. FingerPrint Mark. [Team project - supervised by A. Hambalík and P. Marák], FEI STU Bratislava : Bratislava, 2016. 